\title{
Comparative Analysis of Antibody and Cell-mediated Autoimmunity to Transaldolase and Myelin Basic Protein in Patients with Multiple Sclerosis
}

\author{
Emanuela Colombo, ${ }^{\star}$ Katalin Banki, ${ }^{\ddagger}$ Arthur H. Tatum, ${ }^{\ddagger}$ John Daucher, ${ }^{\ddagger}$ Pasquale Ferrante, ${ }^{\S}$ Ronald S. Murray, \\ Paul E. Phillips, ${ }^{*}$ and Andras Perl* \\ *Department of Medicine, ${ }^{\ddagger}$ Department of Pathology, State University of New York College of Medicine, Syracuse, New York 13210; \\ ${ }^{\S}$ Don Gnocchi Multiple Sclerosis Center, 20148 Milan, Italy; and ${ }^{\|}$Colorado Multiple Sclerosis Center, Englewood, Colorado 80110
}

\begin{abstract}
Antibody and T cell-mediated immune responses to oligodendroglial autoantigens transaldolase (TAL) and myelin basic protein (MBP) were examined in patients with multiple sclerosis (MS). Immunohistochemical studies of postmortem brain sections revealed decreased staining by MBPand TAL-specific antibodies in MS plaques, indicating a concurrent loss of these antigens from demyelination sites. By Western blot high titer antibodies to human recombinant TAL were found in 29/94 sera and 16/23 cerebrospinal fluid samples from MS patients. Antibodies to MBP were undetectable in sera or cerebrospinal fluid of these MS patients. Proliferative responses to human recombinant TAL (stimulation index $[\mathrm{SI}]=2.47 \pm 0.3$ ) were significantly increased in comparison to MBP in 25 patients with MS (SI = $1.37 \pm 0.1 ; P<0.01$ ). After a 7-d stimulation of PBL, utilization of any of 24 different $T$ cell receptor $V \beta$ gene segments in response to MBP was increased less than twofold in the two control donors and six MS patients investigated. In response to TAL-H, while skewing of individual $\mathrm{V} \beta$ genes was also less than twofold in healthy controls, usage of specific $\mathrm{V} \beta$ gene segments was differentially increased ranging from 2.5 to 65.9-fold in patients with MS. The results suggest that TAL may be a more potent immunogen than MBP in MS. (J. Clin. Invest. 1997. 99:1238-1250.) Key words: transaldolase $\cdot$ myelin basic protein $\bullet$ multiple sclerosis
\end{abstract}

\section{Introduction}

Multiple sclerosis (MS $)^{1}$ is a chronic inflammatory disease of the central nervous system (CNS) characterized by a progressive loss of oligodendrocytes and demyelination in the white matter (1). In the acute stage of disease, lesions contain mac-

\footnotetext{
Address correspondence to Andras Perl, SUNY HSC, 750 East Adams Street, Syracuse, NY 13210. Phone, FAX: 315-464-4192; E-mail: Perla@VAX.CS.HSCSYR.EDU

Received for publication 29 May 1996 and accepted in revised form 6 January 1997.
}

1. Abbreviations used in this paper: Con A, concanavalin A; CSF, cerebrospinal fluid; EAE, experimental allergic encephalomyelitis; GFAP, glial fibrillary acidic protein; GST, glutathione S-transferase; MBP, myelin basic protein; MS, multiple sclerosis; OND, other neurological diseases; PPP, pentose phosphate pathway; r, recombinant; SI, stimulation index; TAL, transaldolase; TAL-H, human TAL.

J. Clin. Invest.

(C) The American Society for Clinical Investigation, Inc. 0021-9738/97/03/1238/13 \$2.00

Volume 99, Number 6, March 1997, 1238-1250 rophages, $\mathrm{T}$ cells, and immunoglobulin deposits, suggesting that the demyelination process is mediated by the immune system (2-5). The inflammatory picture of early lesions, which is followed by a progressive gliosis, also suggested that the pathological process may be initiated by infectious agents and then self-perpetuated by a cross-reactive autoimmune process (6-11). Although the antigen(s) driving this self-destructive process in MS has not been identified, the importance of myelin-derived antigens was demonstrated by their abilities to elicit an MS-like demyelinating disease, experimental allergic encephalomyelitis (EAE), in various animal models $(1,12)$.

The major difficulties in applying the EAE model to MS stem from a lack of identification of relevant autoantigen(s). Studies on relapsing EAE have shown that different encephalitogenic molecules or epitopes within them are selected that are compatible with the heterogeneity of the immune response in MS, suggesting that disease initiation and relapse episodes are induced by different neuroantigens $(13,14)$. Most efforts have been focused on myelin basic protein (MBP) and proteolipid protein that make up as much as 30 and $50 \%$ of CNS myelin, respectively (15). Thus, MBP and proteolipid protein are likely to be prominent targets of an autoimmune response secondary to tissue injury in the CNS. Nevertheless, T cell responses to MBP and proteolipid protein did not differ considerably between MS patients and control donors (1).

Previous studies from this laboratory, pursuing the goal to isolate autoantigens containing epitopes cross-reactive with viral proteins, demonstrated that an autoantigen, partially encoded by a retrotransposon and selectively expressed in oligodendrocytes at high levels (16), corresponds to transaldolase (17), a rate-limiting enzyme of the pentose phosphate pathway (PPP). Although glucose is largely metabolized through the glycolytic pathway and the tricarboxylic acid cycle, the significance of PPP in the brain has long been established. During brain development PPP provides fundamental factors for the biosynthesis of nucleic acids and lipids (18). The latter is particularly important at the period of active myelination $(19,20)$. The overall activity of PPP in the brain declines fivefold from birth to maturity (21). Whereas under normal conditions only as little as $1 \%$ of the glucose is metabolized through the PPP in the brain (22), at times of rapid myelination up to $60 \%$ of the glucose used by the brain is metabolized via the PPP linked to the high rate of lipid biosynthesis (23). Another fundamental function of PPP is to maintain glutathione in a reduced state and thus provide protection of sulfhydryl groups and cellular integrity from emerging oxygen radicals (18). Oligodendrocyte-specific expression of TAL is possibly linked to production of large amounts of lipids, as a major component of myelin, and protection of the vast network of myelin sheaths from oxygen radicals. In the present study, we show that similar to MBP, transaldolase (TAL) is selectively depleted in demyelinating plaque lesions of MS brains. Patients with MS have an- 
$\mathbf{A}$

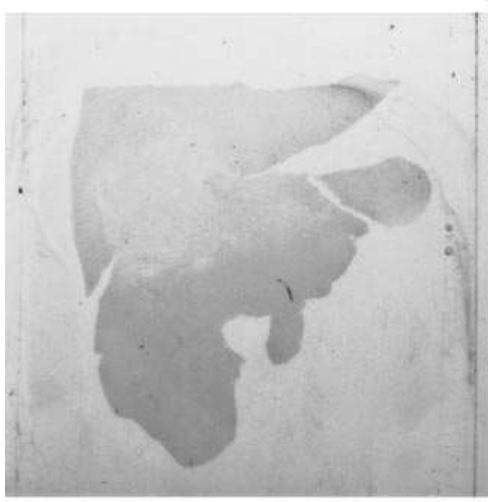

B

C

D

E
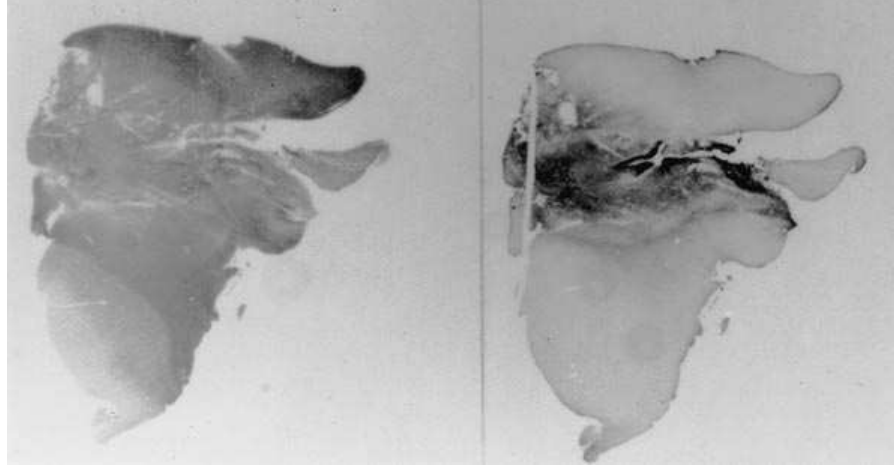

F

G 


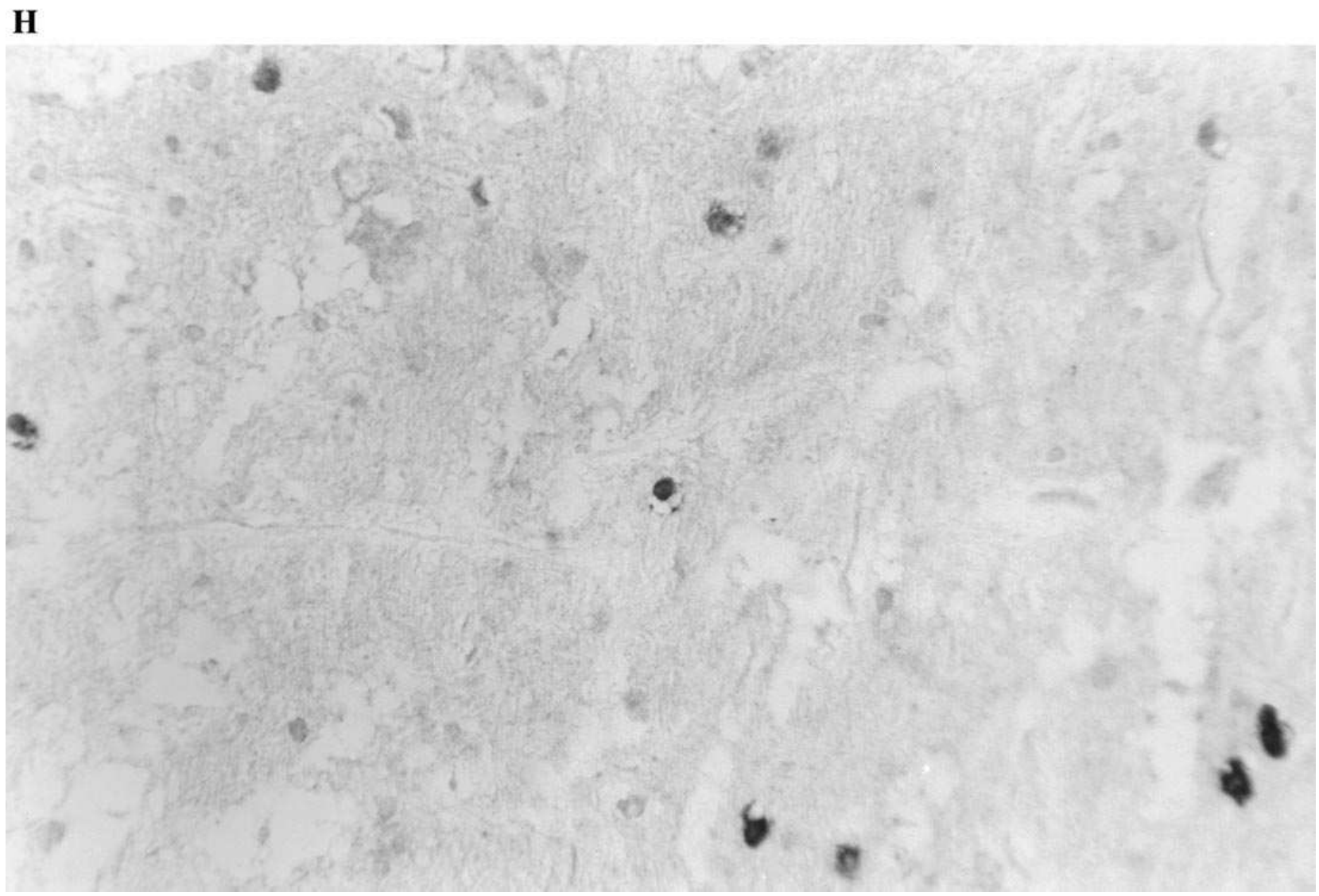

Figure 1. Parallel frozen sections of human postmortem brain tissue from a donor with MS (MS3/H) were stained with anti-TAL-H rabbit antibody $169(A)$, anti-MBP rabbit antibody $(B)$, control 169 preimmune rabbit serum $(C)$, neurofilament-specific $\mathrm{mAb}$ SMI $312(D)$, and antiGFAP rabbit serum $(E)$. Slides were developed using biotinylated goat anti-rabbit IgG or anti-mouse IgG, peroxidase-conjugated streptavidin, and substrate. Section F was counter-stained with hematoxylin. Marked decrease of immunoreactivity with anti-TAL and anti-MBP antibodies and increased staining with anti-GFAP antibody in a defined circular area corresponds to a demyelinating plaque lesion. Magnification, 4. Higher power photographs $(\times 400)$ of anti-TAL-H antibody-stained section A show absence of oligodendrocyte-specific immunoreactivity in center of the plaque area $(G)$ and staining of oligodendrocytes in adjacent normal white matter $(H)$.

tibodies to TAL in their blood (29/94) and cerebrospinal fluid (CSF) (16/23), whereas human TAL (TAL-H) antibodies are absent in normal individuals and patients with other autoimmune and neurological diseases (16). Antibodies to MBP were not found in serum and CSF of MS patients. In addition, TAL-H elicited a skewing of the T cell receptor (TCR) V $\beta$ repertoire of peripheral blood T lymphocytes from patients with MS in comparison to $\mathrm{MBP}$ as a control antigen. These results suggested that TAL-H may be a more significant target than MBP of myelinreactive $\mathrm{T}$ cells and of humoral autoreactivity in MS patients.

\section{Methods}

Patients and human tissue samples. Patients included 94 with MS and, as controls, 9 patients with other neurological diseases (OND), 10 patients with SLE, and 74 healthy subjects. All patients satisfied the criteria for a definitive diagnosis (24). Patients with MS were diagnosed according to the criteria of Poser et al. (25). Patients with OND were diagnosed with acute meningitis (1), Parkinson's disease (1), progressive multifocal leukoencephalopathy (1), paresthesias (1), and cerebrovascular disease (5). Matching CSF and blood samples from patients with MS were kindly provided by Dr. W.W. Tourtelotte from the National Neurological Research Specimen Bank, Veterans Administration Medical Center, Los Angeles, CA. Coronal brain sec- tions from four donors with MS were obtained from the Rocky Mountain Multiple Sclerosis Center, Englewood, CO.

Immunohistochemistry. Formalin-fixed ( $10 \%$ formaldehyde in PBS) and paraffin-embedded sections of human postmortem brain tissue from 10 donors without neurological disorder and from four patients with MS were stained with control 169 preimmune rabbit serum, anti-TAL-H immune rabbit serum 169 (17), anti-MBP rabbit serum, and anti-glial fibrillary acidic protein (GFAP) rabbit serum (DAKO, Glostrup, Denmark) at dilutions of 1:5,000. Slides were developed using biotinylated goat anti-rabbit $\mathrm{IgG}$ and alkaline phosphatase-conjugated streptavidin, and substrate (all from DAKO). Neurofilament-specific mAb SMI 312 was obtained from Sternberger Monoclonals (Baltimore, MD).

Antigens and antibodies. Full-length recombinant TAL-H protein was expressed as a fusion protein with glutathione S-transferase (GST) encoded by pGEX-2T plasmid vector (26), affinity-purified through binding of GST to glutathione-coated agarose beads, cleaved from GST by 1 NIH unit of thrombin (Sigma Chemical Co., St. Louis, $\mathrm{MO}$ ), and separated from the agarose bead-bound GST by centrifugation (16). Control GST antigen was prepared by elution from glutathione-coated agarose beads in $10 \mathrm{mM}$ reduced glutathione, $50 \mathrm{mM}$ Tris- $\mathrm{HCl}, \mathrm{pH}$ 8.0. The purified full-length recombinant TAL-H was analyzed by SDS-PAGE and Western blot and tested for TAL enzyme activity as earlier described $(17,27)$. MBP was purified from neurologically normal human brain according to the procedure of 
Deibler et al. (28). Purity of the MBP preparations was analyzed by SDS-PAGE and Western blot. Tetanus toxoid was obtained from Wyeth Laboratories (Marietta, PA). Concanavalin A (Con A) was purchased from Sigma. Highly specific polyclonal rabbit antibodies 169 and 170 directed to the 139 amino acid long $\mathrm{NH}_{2}$-terminal segment of TAL-H were developed earlier (17). Antibody to MBP was obtained from DAKO (Carpinteria, CA).

Western blot analysis. $500 \mathrm{ng}$ recombinant TAL-H protein in 10 $\mu l$ per well was separated by SDS-PAGE and electroblotted to nitrocellulose (29). Nitrocellulose strips were incubated in $100 \mathrm{mM}$ Tris, $\mathrm{pH} 7.5,0.9 \% \mathrm{NaCl}, 0.1 \%$ Tween 20 , and $5 \%$ skim milk with antibodies (at a 1,000-fold dilution unless indicated otherwise) for $1 \mathrm{~h}$ at room temperature. For detection of rabbit antibodies, after washing, the strips were incubated with horseradish peroxidase-conjugated goat anti-rabbit IgG (Boehringer Mannheim, Indianapolis, IN). For detection of human antibodies, after washing the strips were incubated with biotinylated goat anti-human serum and, subsequently, with horseradish peroxidase-conjugated avidin (Jackson Laboratories, West Grove, PA). In between the incubations, the strips were vigorously washed in $0.1 \%$ Tween-20, $100 \mathrm{mM}$ Tris $\mathrm{pH} 7.5$, and $0.9 \%$ $\mathrm{NaCl}$. The blots were developed with a substrate comprised of $1 \mathrm{mg} /$ $\mathrm{ml}$ 4-chloronaphthol and $0.003 \%$ hydrogen peroxide.

Testing of TAL enzyme activity. TAL enzyme activity was measured by the transfer of the dihydroxyacetone three-carbon unit from the donor D-fructose-6-phosphate, to the acceptor D-erythrose-4phosphate (27). Enzyme activity was assayed in the presence of 3.2 $\mathrm{mM}$ D-fructose 6-phosphate, $0.2 \mathrm{mM}$ D-erythrose-4-phosphate, 0.1 $\mathrm{mM}$ NADH, $10 \mu \mathrm{g} \alpha$-glycerophosphate dehydrogenase/triosephosphate isomerase at a 1:6 ratio in $1 \mathrm{ml}$ phosphate buffered saline, $\mathrm{pH}$ 7.4 , at room temperature by continuous absorbance reading at 340 $\mathrm{nm}$ for $20 \mathrm{~min}$. The assay was conducted in the activity range of $0.001-0.01 \mathrm{U} / \mathrm{ml}$.

Stimulation of $P B L$. PBMC were isolated from heparinized venous blood on Ficoll-Hypaque gradient and resuspended in RPMI 1640 medium, supplemented with $10 \%$ FCS, 2 mM L-glutamine, $100 \mathrm{IU} / \mathrm{ml}$ penicillin, and $100 \mu \mathrm{g} / \mathrm{ml}$ gentamicin. $10^{5}$ cells were incubated in each well of a microtiter plate using six parallel samples. Concentration ranges of $1-30 \mu \mathrm{g} / \mathrm{ml}$ for TAL-H and $1-100 \mu \mathrm{g} / \mathrm{ml}$ for MBP were tested. $5 \mu \mathrm{g} / \mathrm{ml}$ for TAL-H and $30 \mu \mathrm{g} / \mathrm{ml}$ for MBP were found to be optimal to induce cell proliferation. Negative control and positive control cultures (containing $10 \mu \mathrm{g} / \mathrm{ml}$ Con A or $10 \mu \mathrm{g} / \mathrm{ml}$ tetanus toxoid) were included in each experiment. $5 \mu \mathrm{g} / \mathrm{ml}$ affinity-purified GST was used as a negative control antigen. The plates were incubated at $37^{\circ} \mathrm{C}$ in a humidified atmosphere with $5 \% \mathrm{CO}_{2}$ for $72 \mathrm{~h}$. The cultures were pulsed with $0.4 \mu \mathrm{Ci}{ }^{3} \mathrm{H}$-TdR $8 \mathrm{~h}$ before termination. Cells were harvested and ${ }^{3} \mathrm{H}-\mathrm{TdR}$ incorporation was measured as earlier described (30). The results were expressed in counts per min as mean \pm standard error (SE) of six parallel cultures. Stimulation indices (SIs) are given as mean \pm SD of $n$ experiments. Mean values ( \pm SD) were compared using Student's $t$ test. Correlations were analyzed by linear regression. $P$ values $<0.05$ were considered significant (31).

Analysis of the TCR V $\beta$ repertoire by reverse-transcriptase $(R T)$ $P C R$. Total cellular RNA was isolated from cultured cells by the RNAzol method (32). $3 \mu \mathrm{g}$ of RNA was reverse transcribed into cDNA with oligo-dT primer by $200 \mathrm{U}$ of Superscript reverse transcriptase according to the manufacturer's protocol (GIBCO-BRL, Bethesda, MD). For analysis of TCR V $\beta$ gene usage, cDNA aliquots were subjected to PCR using $24 \mathrm{~V} \beta$ sense strand-specific oligonucleotides in combination with an antisense strand-specific $\mathrm{C} \beta$ primer (CßREVF, 5' -CGGGCTGCTCCTTGAGGGGCTGCG-3') (33). As an internal control, each PCR reaction included $\mathrm{C} \alpha$-specific sense (C $\alpha$-FWJ, 5'-CCCTGACCCTGCCGTGTACCAGCT-3') and antisense primers (C $\alpha$ REVE, 5'-GTTGCTCCAGGCCGCGGCACTGTT-3') (33). Amplifications were carried out in 30 cycles at a denaturing temperature of $94^{\circ} \mathrm{C}(1 \mathrm{~min})$, annealing at $60^{\circ} \mathrm{C}(1 \mathrm{~min})$, and extension at $72^{\circ} \mathrm{C}(2 \mathrm{~min})$. Amplified products were analyzed by electrophoresis in $2 \%$ agarose gel, transferred to Zetabind membrane (Bio-Rad, Richmond, CA) in $0.4 \mathrm{~N} \mathrm{NaOH}$, and hybridized to an internal

end-labeled $\mathrm{C} \alpha$ (C $\alpha$ REVC, 5'-GTCACTGGATTTAGAGTCT-3') or C $\beta$ (CßREVb, 5'-GGTGTGGGAGATCTCTGCTTCTG-3' corresponding to positions $128-106$ in the $\mathrm{C} \beta 2$ gene) primers (33). Blots were exposed to phosphor storage screen and analysed using a computerized phosphorimager (Molecular Dynamics, Sunnyvale, CA). All signals for the $24 \mathrm{~V} \beta$ families together were scored as $100 \%$. Data show mean of duplicate analyses. In accordance with previous data (34), repeated antigen stimulation and RT-PCR analyses of the TCR $\mathrm{V} \beta$ repertoire consistently gave variations $<10 \%$ in use of individual $\mathrm{V} \beta$ gene families.

\section{Results}

Selective loss of MBP and TAL-H in MS plaques. Immunohistochemical analysis of postmortem sections revealed that expression of TAL-H is specific for oligodendrocytes in the human brain (16). Localization of TAL-H to oligodendroglia was confirmed by parallel staining for MBP and galactocerebroside (which showed concordant staining pattern with TAL-H) and GFAP (which showed astrocyte-specific discordant staining pattern relative to TAL-H). Since demyelination in MS results from damage to oligodendrocytes, presence of TAL-H in MS brain sections was investigated. Concordant loss of TAL-H and MBP within demyelinating lesions was noted in parallel sections from the brain of a 38-yr-old female with an 8-yr history of MS (MS3/H) using TAL-H specific rabbit antibody 169 and an MBP-specific rabbit antibody, respectively (Fig. 1, $A$ and $B$ ). As a negative control, parallel sections were simultaneously stained with 169 preimmune rabbit serum (Fig. $1 C$ ). Maintenance of axons and increased expression of GFAP within the plaque area was visualized by staining with neurofilament-specific mAb SMI 312 and a GFAP-specific rabbit antibody, respectively (Fig. 1, $D$ and $E$ ). Absence of oligodendrocyte-specific immunoreactivity in center of the plaque area (Fig. $1 \mathrm{G}$ ) and staining of oligodendrocytes in adjacent normal white matter with anti-TAL-H antibody are shown in Fig. $1 \mathrm{H}$. Similar findings were obtained in three additional MS brain specimens (MS1/C, MS2/R, and MS3/M; not shown).

Presence of antibodies to TAL-H and absence of antibodies to $M B P$ in patients with $M S$. Oligodendrocytes are selectively

A

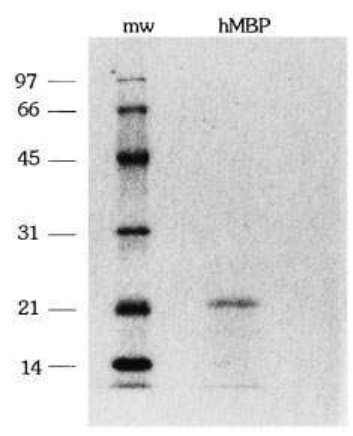

Figure 2. (A) SDS-PAGE of human MBP $(h M B P)$ purified from neurologically normal human brain. $(B)$ Western blot detection of hMBP using MBP-specific rabbit antibody (left). Lack of immunological cross-reactivity between TAL-H antibody 169 and hMBP (right). 


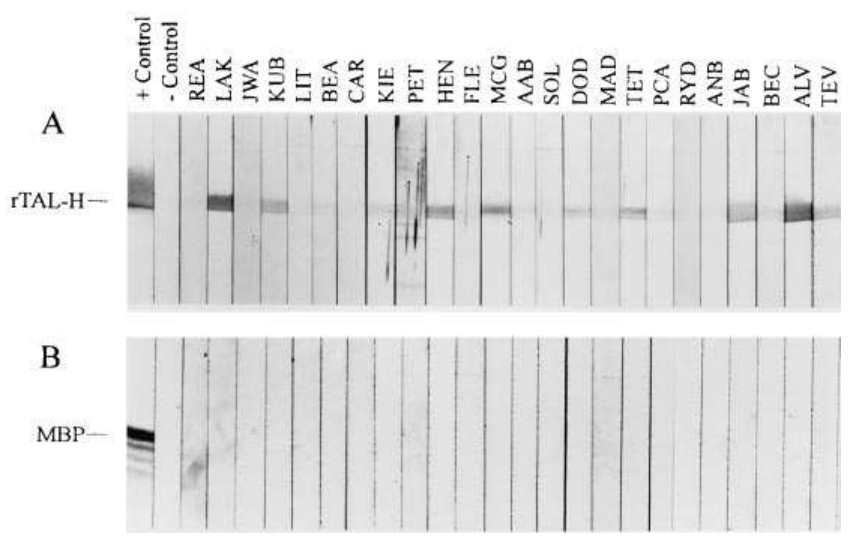

Figure 3. Western blot reactivity to affinity-purified $38-\mathrm{kD}$ fulllength rTAL-H $(A, 500 \mathrm{ng} /$ lane $)$ and human $\operatorname{MBP}(B, 500 \mathrm{ng} /$ lane $)$ of sera from patients with MS at a dilution of 1:100. + control indicates TAL-H-specific rabbit antibody 169 in $A$ and MBP-specific rabbit antibody in $B ;-$ control, normal human serum. Sera of patients KUB, HEN, MCG, TET, JAB, and TEV were TAL-H reactive up to a dilution of 1:1,000, while sera of patients LAK and ALV were TAL-H reactive up to a dilution of 1:10,000 (not shown).

destroyed in patients with MS by an oligodendrocyte-specific immune-mediated process. Recognition of oligodendroglial autoantigens, TAL-H and MBP, was investigated by antibodies in sera from 94 patients with MS, 10 patients with SLE, 9 patients with OND, and 74 control blood donors. TAL-H-specific seropositivity was based on immunoreactivity to recombinant protein (500 ng/lane) at serum dilutions of 1:100 or higher using Western blot analysis. Enzymatic activity and purity of each recombinant (r)TAL-H preparation was controlled by SDS-PAGE and Western blot (Fig. 2). In accordance with earlier data (16), presence of TAL-H autoantibodies was highly specific for MS. TAL-specific antibodies were detected in 29/ 94 patients with MS. TAL antibodies were not detectable in patients with SLE, OND, or in control donors. Representative data are shown in Fig. 2. Thus, detection of TAL-H autoantibodies in patients with MS is a highly significant finding as compared to control and other autoimmune disease groups $(P<$ 0.001 , using chi-square test). No correlation was found between TAL-H seropositivity and immunoglobulin concentrations in the sera of seven patients with MS and four control donors (data not shown).

Humoral autoreactivity to TAL-H was compared to that against MBP purified from neurologically normal human brain according to the procedure of Deibler et al. (28). Purity of the MBP preparations was analyzed by SDS-PAGE and Western blot. The MBP antigen used was essentially free from other brain proteins and no immunological cross-reactivity between MBP and TAL-H was observed (Fig. 2). In contrast to TAL-H, antibodies to MBP were absent in all MS sera tested at a dilution of 1:100 using $500 \mathrm{ng}$ of purified human MBP antigen per lane (representative results are shown in Fig. 3).

Most patients with MS have a disease course characterized by relapses and remissions, termed relapsing/remitting MS. A minority of patients have a primarily chronic progressive disease. Many of the R/R patients will, nevertheless, eventually enter a phase of secondary progressive evolution of symptoms. TAL-H immunoreactivity of sera from seven antibody-posi-

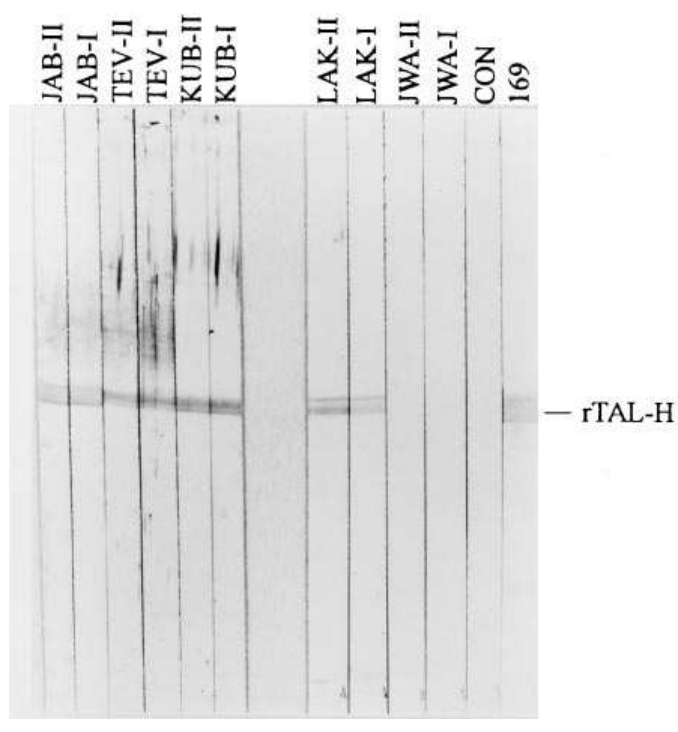

Figure 4. Western blot reactivity to rTAL-H (38 kD) was sequentially tested in 100-fold diluted sera from patients JAB, TEV, KUB, LAK, and JWA. I, first sample; $I I$, second sample 6 mo later. $C O N$, negative control human serum; 169 , rabbit antibody to TAL-H.

tive and eight antibody-negative patients was sequentially tested and gave identical results on two different occasions 6 mo apart. Representative results are shown in Fig. 4. This suggested that TAL-H seroreactivity is a stable marker in a subset of patients with MS.

Detection of antibodies to TAL-H but not to MBP in CSF of $M S$ patients. In previous and present analyses antibody to TAL-H was noted in 15/20 CSF samples from patients with MS. No TAL-H antibody was found in the CSF of control donors with other neurological diseases (not shown). 13/17 CSF samples from TAL-H-seropositive MS patients contained antibody to TAL-H. 2/3 additional CSF samples from MS patients with no available serum specimen also contained TAL-H antibodies. Representative data are shown in Fig. 5. Antibodies to TAL-H were noted in a total of $16 / 23 \mathrm{CSF}$ samples from patients with MS. Under identical conditions antibody to MBP could not be detected in CSF samples of any of the MS patients at a 1:2 dilution (not shown). This was consistent with

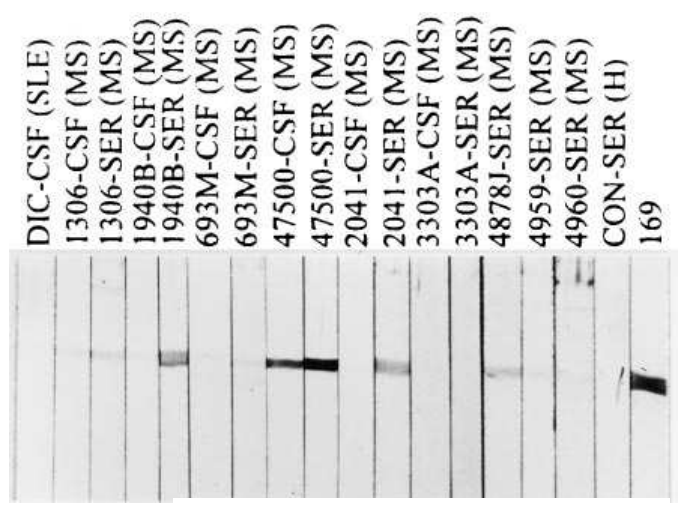

Figure 5. Immunoreactivity to recombinant TAL-H of paired serum (SER) and CSF samples of TAL-H-seropositive patients with MS and a control SLE patient $(D I C)$ and healthy donors $(H)$. 


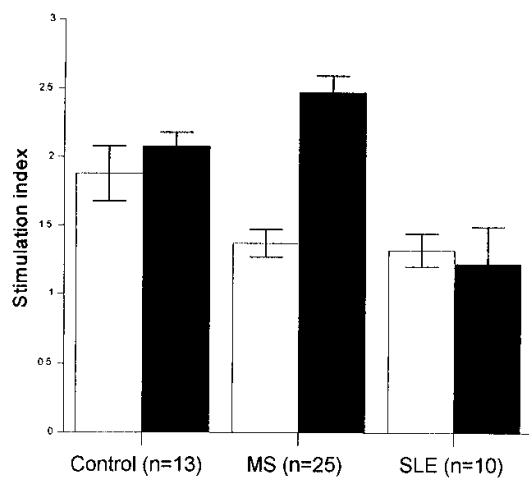

B

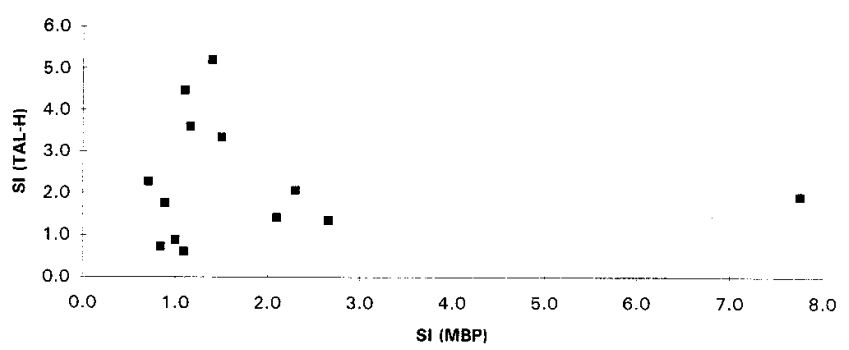

MS patients $(p<0.001)$

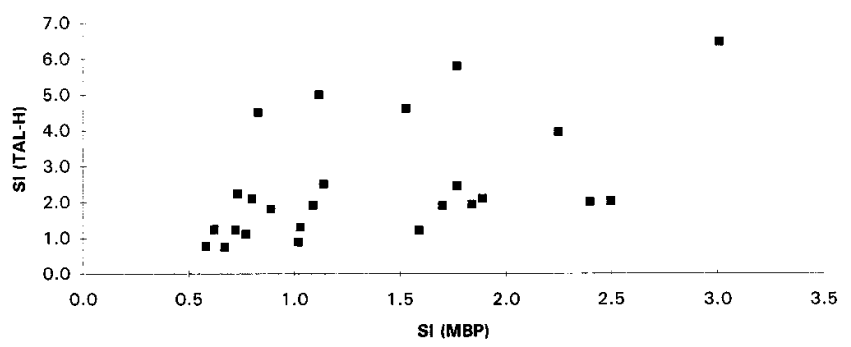

Figure 6. (A) Proliferative responses by PBLs to TAL-H and MBP in 13 control donors, 25 patients with MS, and 8 patients with SLE. SIs were measured in the absence or presence of $50 \mathrm{U} / \mathrm{ml}$ human recombinant IL-2 in response to $5 \mu \mathrm{g} / \mathrm{ml}$ TAL-H (shaded bars) or $30 \mu \mathrm{g} / \mathrm{ml}$ MBP (open bars). Significant differences were observed in patients with MS between responses to TAL-H and MBP in the presence or absence of IL-2. (B) Relationship of proliferative responses to TAL-H and MBP in control donors and patients with MS and SLE. Each data point represents the mean of six parallel cultures. Significant covariance of SIs in response to TAL-H and MBP were noted in patients with MS $(P<0.001)$; n.s., not significant. previous data showing that MBP-specific immunity in MS is primarily $\mathrm{T}$ cell mediated $(1,35)$. Thus, in comparison to MBP, TAL-H is a prominent target of humoral autoreactivity in MS.

Stimulation of $P B L$ proliferation by $T A L-H$. It is generally accepted that autoreactive $\mathrm{T}$ cells in patients with MS recognize oligodendroglial antigens (1). To investigate whether TAL-H may be a target of autoreactive $\mathrm{T}$ cells, its effect on proliferation of PBL was evaluated. Highly purified recombinant TAL-H antigen was used in these studies to ensure that the responses detected were not directed to any other myelin protein. Addition of $5 \mu \mathrm{g} / \mathrm{ml}$ TAL-H significantly increased proliferation of lymphocytes from 25 patients with MS $(P<$ $0.001)$. The SI varied between 0.8 and 6.5 -fold among the patients (Fig. 6). Lymphocytes were incubated in the presence of $10 \%$ autologous serum. Heat inactivation of autologous serum or use of $10 \%$ FCS had no significant effect on the proliferative responses to TAL-H. By contrast, proliferation of lymphocytes from normal donors or patients with SLE was not significantly increased in the presence of TAL-H. $5 \mu \mathrm{g} / \mathrm{ml}$ rTAL-H was repeatedly found to be a significantly more po- 


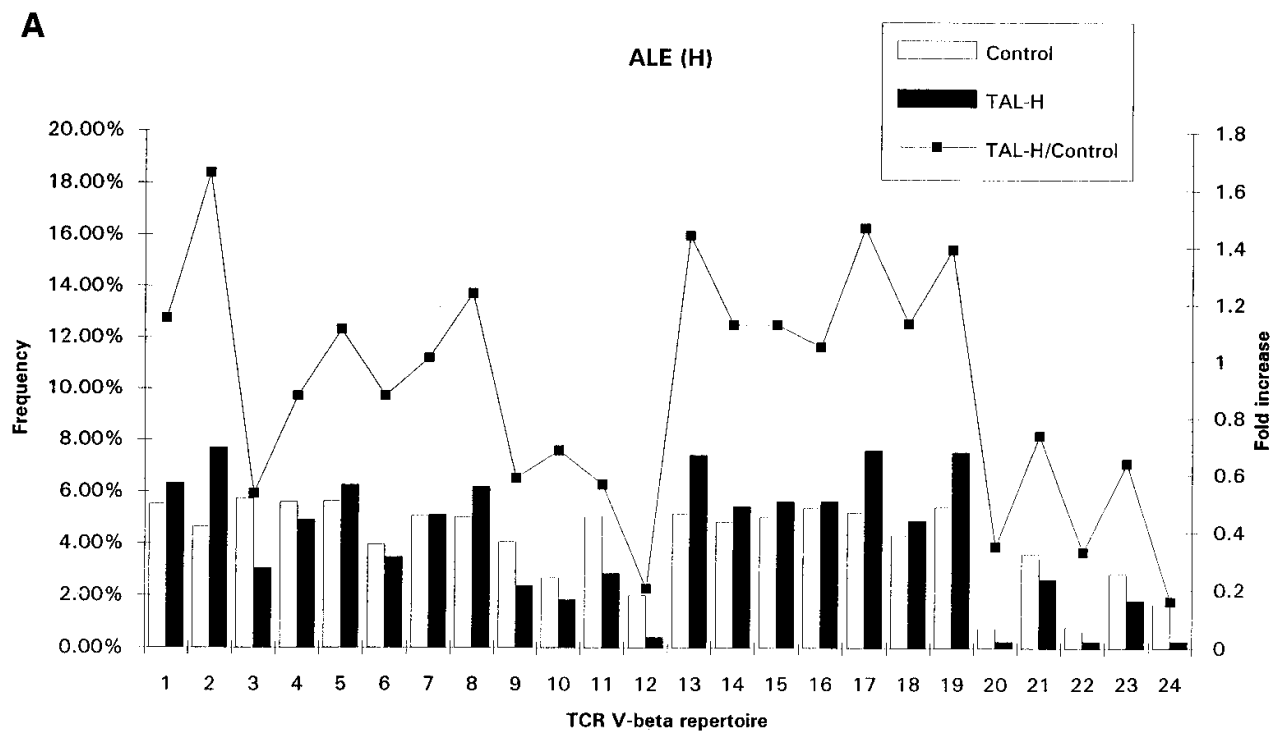

B

STR (H)

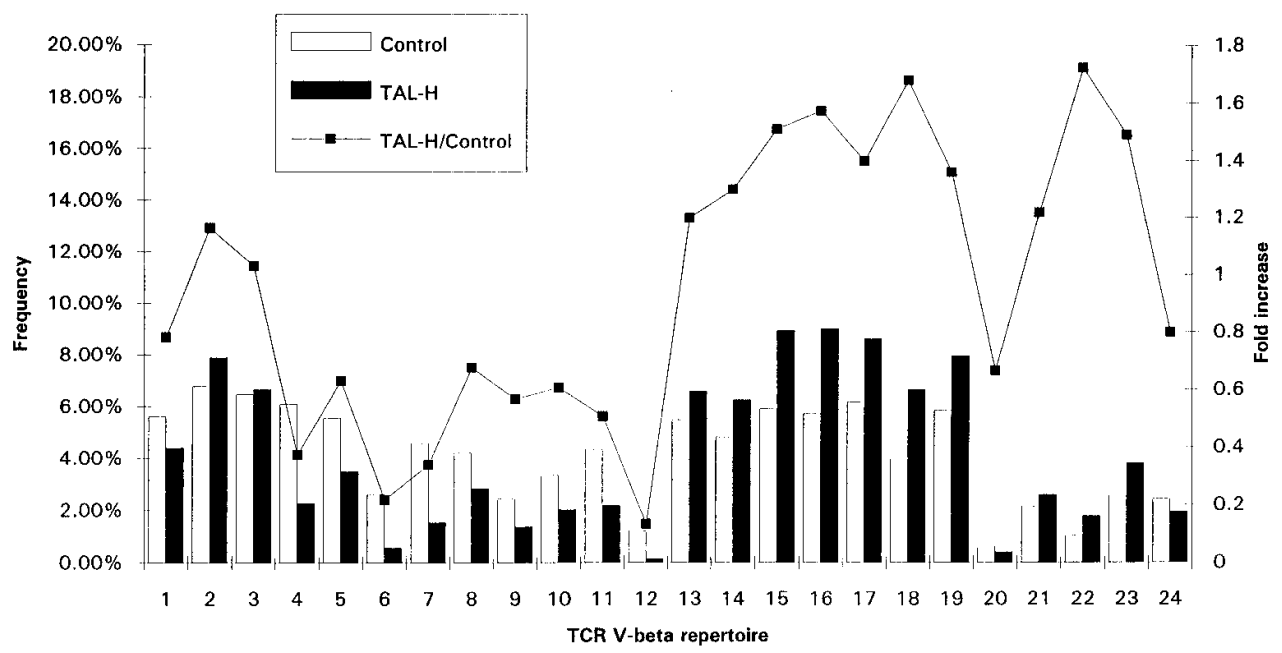

C

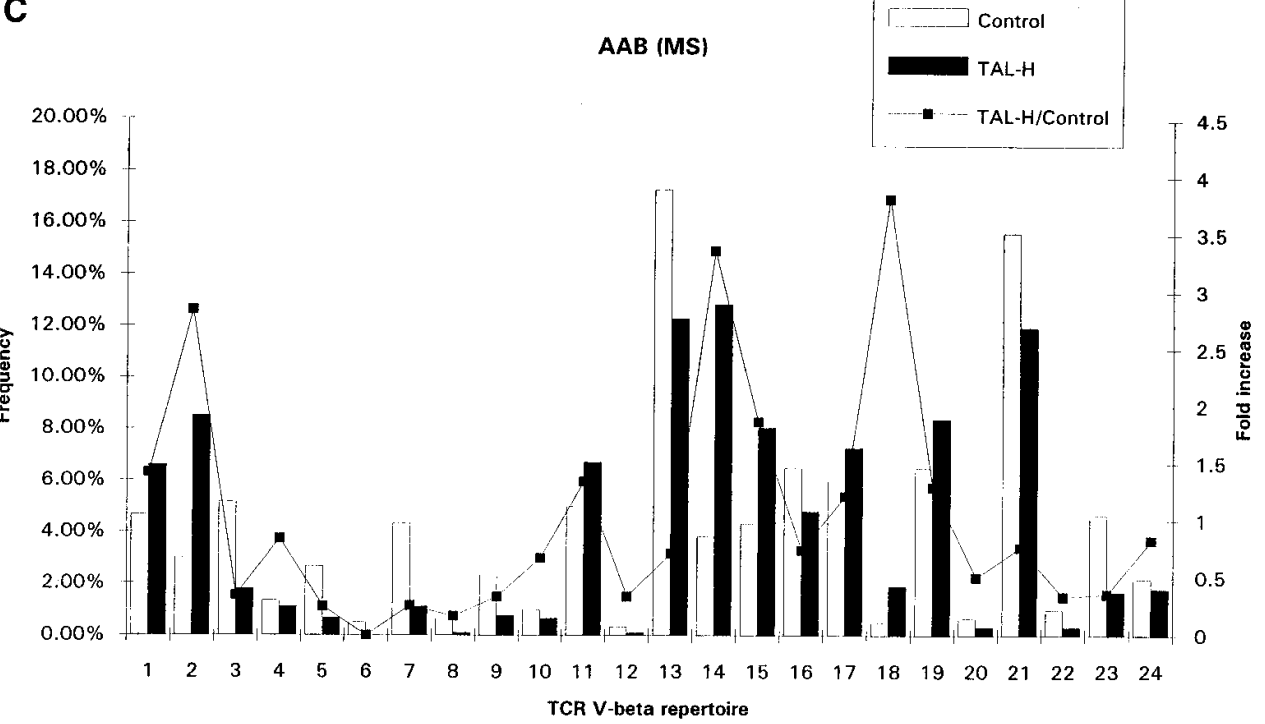



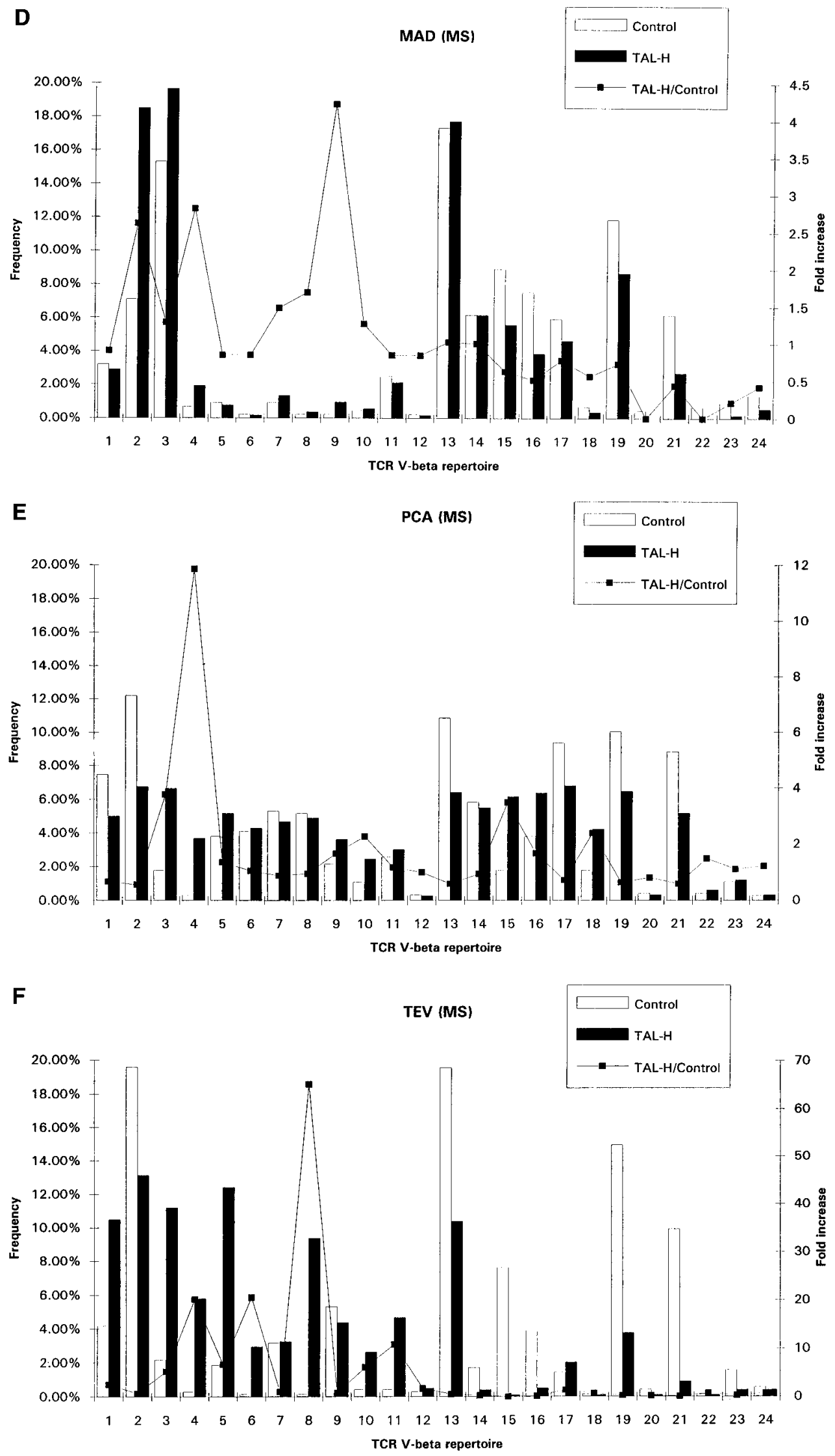

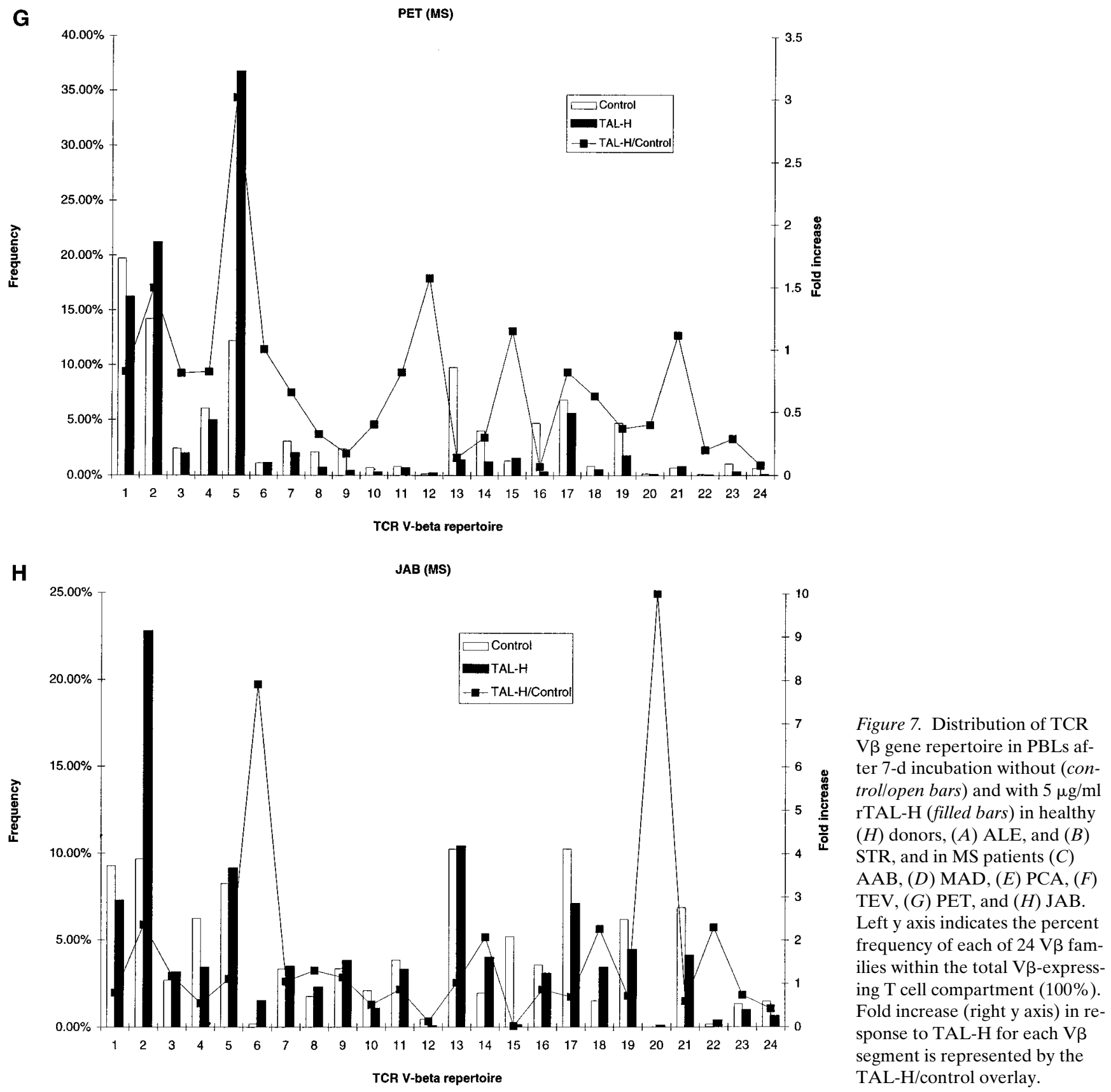

tent stimulator of lymphocyte proliferation than $30 \mu \mathrm{g} / \mathrm{ml}$ MBP $(P<0.001 ;$ Fig. $6 A)$. At these optimal concentrations (5 $\mu \mathrm{g} / \mathrm{ml}$ TAL-H and $30 \mu \mathrm{g} / \mathrm{ml}$ MBP), TAL SI $\geq 2$ was noted in $14 / 25$ patients (Fig. $6 B$ and Table I) whereas MBP SI $\geq 2$ was noted in $4 / 25$ patients with MS. TAL-H concentrations higher than $5 \mu \mathrm{g} / \mathrm{ml}(10$ and $30 \mu \mathrm{g} / \mathrm{ml})$ and MBP concentrations higher than $30 \mu \mathrm{g} / \mathrm{ml}(50$ and $100 \mu \mathrm{g} / \mathrm{ml})$ resulted in no further increase of $\mathrm{T}$ cell proliferation. Affinity-purified recombinant GST expressed from the $\mathrm{pGEX}-2 \mathrm{~T}$ vector also failed to stimulate lymphocyte proliferation. No differences in proliferative responses to $10 \mu \mathrm{g} / \mathrm{ml}$ tetanus toxoid were observed among the donor groups investigated (not shown).

Previous studies suggested that the frequency of MBPreactive $T$ cells was increased among in vivo-activated IL-2- responsive T cells (36). To compare the reactivity to TAL-H with that to MBP by in vivo-activated $\mathrm{T}$ cells, proliferative responses were evaluated in the presence of human recombinant IL-2. ${ }^{3} \mathrm{H}-\mathrm{TdR}$ incorporation was increased by IL-2 5.2 \pm 0.6 fold in control donors, 3.8 \pm 0.5 -fold in patients with MS, and $1.9 \pm 0.5$-fold in patients with SLE. Thus, in accordance with earlier data (37), responsiveness to IL-2 was significantly impaired in patients with SLE $(P<0.001)$. Proliferation of IL-2stimulated cells was further increased by rTAL-H in patients with MS $(P<0.001)$. MBP had no significant effect on proliferation of IL-2-stimulated cells in any of the donor groups investigated.

In patients with MS, SIs in response to TAL-H ranged from 0.8-6.5-fold, whereas SIs in response to MBP ranged 
Table I. Disease Data of Patients with Increased Proliferative Responses to rTAL-H

\begin{tabular}{llcclc}
\hline Patient & Age/Sex & Dx duration & Dx type & TAL antibody & TAL SI \\
\hline TEVE & $41 / \mathrm{F}$ & $13 \mathrm{yr}$ & $\mathrm{R} / \mathrm{R}$ & $>1: 1,000$ & 6.5 \\
LIT & $72 / \mathrm{F}$ & $43 \mathrm{yr}$ & $\mathrm{R} / \mathrm{R}$ & - & 5.8 \\
PET & $45 / \mathrm{F}$ & $15 \mathrm{yr}$ & $\mathrm{R} / \mathrm{R}$ & $>1: 100$ & 5.0 \\
ALV & $57 \mathrm{~F}$ & $20 \mathrm{yr}$ & $\mathrm{CP}$ & $>1: 10,000$ & 4.6 \\
ROB & $32 / \mathrm{M}$ & $1 \mathrm{mo}$ & $\mathrm{A}$ & $>1: 10,000$ & 4.5 \\
JAB & $42 / \mathrm{F}$ & $10 \mathrm{yr}$ & $\mathrm{R} / \mathrm{R}$ & $>1: 1,000$ & 4.0 \\
RYD & $45 \mathrm{~F}$ & $21 \mathrm{yr}$ & $\mathrm{R} / \mathrm{R}$ & - & 2.5 \\
SOL & $69 / \mathrm{M}$ & $29 \mathrm{yr}$ & $\mathrm{S}$ & $>1: 100$ & 2.4 \\
GAU & $36 / \mathrm{F}$ & $15 \mathrm{mo}$ & $\mathrm{R} / \mathrm{R}$ & $>1: 10,000$ & 2.2 \\
DOD & $76 / \mathrm{F}$ & $23 \mathrm{yr}$ & $\mathrm{S}$ & $>1: 100$ & 2.1 \\
MAD & $51 / \mathrm{F}$ & $4 \mathrm{yr}$ & $\mathrm{CP}$ & - & 2.1 \\
AAB & $33 / \mathrm{M}$ & $7 \mathrm{yr}$ & $\mathrm{R} / \mathrm{R}$ & $>1: 100$ & 2.0 \\
LAK & $39 / \mathrm{F}$ & $5 \mathrm{yr}$ & $\mathrm{R} / \mathrm{R}$ & $>1: 10,000$ & 2.0 \\
PCA & $43 / \mathrm{F}$ & $18 \mathrm{yr}$ & $\mathrm{CP}$ & $>1: 100$ & 2.0 \\
& & & & & \\
\hline
\end{tabular}

SI was measured in the presence of $10 \%$ autologous serum in response to $5 \mu \mathrm{g} / \mathrm{ml}$ rTAL-H in comparison with control cultures. TAL-H antibody titers were determined by Western blot; -, titer $<1: 100$. Dx, diagnosis; $\mathrm{M}$, male; $\mathrm{F}$, female; $\mathrm{R} / \mathrm{R}$, relapsing/remitting; $\mathrm{CP}$, chronic progressive; $\mathrm{A}$, acute; $\mathrm{S}$, stable.

from 0.7-3.0-fold (Fig. 6 B). Proliferative responses to TAL were generally twofold increased in comparison with those to MBP $(P<0.001)$. Additionally, a significant covariance in the extent of TAL- and MBP-induced stimulations was noted in patients with MS $(P<0.001)$. Patients with high responsiveness to TAL-H also showed high responsiveness to MBP and donors with low TAL-induced proliferation showed low MBPinduced proliferation as well. No such correlation was observed in control and SLE donors.

Cell proliferation was stimulated twofold or more by TAL-H in 14/25 patients with MS (Table I). Antibodies to TAL-H were more prevalent in patients with $\mathrm{SI} \geq 2(11 / 14)$ in comparison to patients with $\mathrm{SI} \leq 2(3 / 11 ; P<0.05)$. Correlation of celland antibody-mediated immune responses may also indicate sensitization of the immune system to the normally sequestered TAL antigen in a subset of patients with MS. Duration, type, or activity of disease or age of onset did not correlate with $\mathrm{T}$ cell responses or antibody production against TAL.

Skewing of TCR V $\beta$ gene usage in response to TAL-H in patients with MS. The repertoire of TCR V $\beta$ genes used by PBLs in response to stimulation by TAL-H was investigated in two healthy control donors (ALE and STR) and six patients with MS (MAD, AAB, PCA, TEV, PET, and JAB). PBMC were cultured without antigenic stimulation and in the presence of TAL-H $(5 \mu \mathrm{g} / \mathrm{ml})$, MBP $(30 \mu \mathrm{g} / \mathrm{ml})$, or Con A $(5 \mu \mathrm{g} /$ $\mathrm{ml}$ ) in parallel for $7 \mathrm{~d}$. Total cellular RNA was isolated from cultured cells by the RNAzol method (32). $3 \mu \mathrm{g}$ of RNA was reverse transcribed into cDNA with oligo-dT primer by $200 \mathrm{U}$ of reverse transcriptase and cDNA aliquots were subjected to PCR using $24 \mathrm{~V} \beta$ sense strand-specific oligonucleotides in combination with an antisense strand-specific $C \beta$ primer, C $\beta R E V F$. As an internal control, each PCR reaction included $\mathrm{C} \alpha$-specific sense $(\mathrm{C} \alpha$-FWJ) and antisense primers (C $\alpha \mathrm{REVE})$. Amplified products were electrophoresed in 2\% agarose gel, transferred to Zetabind membrane in $0.4 \mathrm{~N} \mathrm{NaOH}$, and hybridized to internal end-labeled $\mathrm{C} \alpha(\mathrm{C} \alpha \mathrm{REVC})$ and $\mathrm{C} \beta$ primers (C $\beta$ REVB). Blots were exposed to $\mathrm{x}$-ray film and analyzed using a computerized automated densitometer. All signals for the $24 \mathrm{~V} \beta$ families together were scored as $100 \%$. RT-PCR analyses repeated on two occasions gave similar results. In healthy donors the TCR V $\beta$ repertoire displayed a relatively even distribution among the 24 gene families examined (Fig. 7). No single gene segment comprised $>7 \%$ of the total $\mathrm{T}$ cell compartment in normal donors ALE or STR. By contrast, the TCR V $\beta$ repertoire was less evenly distributed in unstimulated PBL of MS patients. Upon stimulation by TAL-H, skewing in representation of any TCR V $\beta$ families was less than twofold in healthy controls (Fig. 7). However, stimulation by TAL-H resulted in a twofold or greater expansion of T cells bearing 15 different TCR V $\beta$ gene segments in the six MS patients studied (Table II). This analysis revealed a diversity of TCR V $\beta$ usage in response to TAL-H. No such shifts in TCR V $\beta$ usage attributable to MBP or Con A were observed in the patients or controls (not shown). V $\beta$ families showing greater than twofold relative expansion in response to TAL-H are cumulatively shown in Table II. Of note, the more profound skewing of the TCR V $\beta$ repertoire was found in patients with the higher proliferative responses to TAL-H $(\mathrm{TEV}, \mathrm{SI}=6.5 ; \mathrm{PET}, \mathrm{SI}=5.0$; $\mathrm{JAB}, \mathrm{SI}=4.0)$. Usage of $\mathrm{V} \beta 4$ and $\mathrm{V} \beta 6$ was increased $\sim 20$ -

Table II. Skewing of TCR V $\beta$ Usage in Response to TAL-H

\begin{tabular}{lll}
\hline \multicolumn{1}{c}{ Donor } & \multicolumn{1}{c}{ V $\beta$ (Fold increase $>2)$} & Percent repertoire \\
\hline MAD (MS) & $\mathbf{2}(2.6) ; \mathbf{4}(2.8) ; \mathbf{9}(4.2)$ & 21.4 \\
AAB (MS) & $\mathbf{2}(2.8) ; \mathbf{1 4}(3.4), \mathbf{1 8}(3.8)$ & 23.3 \\
PCA (MS) & $\mathbf{3}(3.8) ; \mathbf{4}(11.8), \mathbf{1 0}(2.3) ; \mathbf{1 5}(3.5) ; \mathbf{1 8}(2.4)$ & 23.2 \\
TEV (MS) & $\mathbf{1}(2.5) ; \mathbf{3}(5.2) ; \mathbf{4}(20.1) ; \mathbf{5}(6.6) ; \mathbf{6}(20.5) ; \mathbf{8}(65.9) ; \mathbf{1 0}(6.1) ; \mathbf{1 1}(10.9)$ & 56.8 \\
PET (MS) & $\mathbf{5}(3.1)$ & $\mathbf{2}(2.4) ; \mathbf{6}(7.9) ; \mathbf{1 4}(2.1) ; \mathbf{1 8}(2.3) ; \mathbf{2 0}(10) ; \mathbf{2 2}(2.3)$ \\
JAB (MS) & None & 36.7 \\
ALE (Control) & None &
\end{tabular}

Cumulative data of changes in the TCR V $\beta$ chain repertoire PBMC in response to stimulation for $7 \mathrm{~d}$ with $5 \mu \mathrm{g} / \mathrm{ml} \mathrm{rTAL}-\mathrm{H}$. V $\beta$ families showing greater than twofold relative expansion in the presence of TAL-H as compared with unstimulated cultures are shown in bold; percent repertoire indicates proportion of expanded V $\beta$ families within the total TCR V $\beta$ chain repertoire. None, less than twofold change in either of 24 TCR V $\beta$ familes. 
fold, whereas that of V $\beta 8$ was stimulated 65-fold in TEV (Fig. $7 F$ ). Whereas fold increases were more moderate in PET and $\mathrm{JAB}$ than in TEV, the absolute contributions of certain $\mathrm{V} \beta$ genes were as high as $36.7 \%$ (V $\beta 5$ in PET, Fig. $7 G$ ) and $22.8 \%$ (V $\beta 2$ in JAB, Fig. $7 H$ ). V $\beta$ families expanded more than twofold in the presence of TAL-H made up as much as 32.2, 36.74, and $59.8 \%$ of the total TCR V $\beta$ repertoire in patients JAB, PET, and TEV, respectively (Table II).

\section{Discussion}

In this study, we comparatively analyzed antibody- and T cellmediated immune responses to oligodendroglial autoantigens TAL and MBP in patients with MS. In view of its activity to elicit EAE in various animal models, MBP, which comprises $30 \%$ of CNS white matter, has been regarded as the prime candidate autoantigen potentially responsible for triggering pathogenic immune responses in MS (1). However, our present analysis shows that a quantitatively less abundant protein, TAL, comprising $\sim 0.1-0.5 \%$ of the total protein content of oligodendrocytes (data not shown), may be at least as important an antigen as MBP. Indeed, antibodies to affinity-purified rTAL-H were found in 29/94 sera and in 16/23 CSF samples from patients with MS. While the amount of TAL-H antibodies was 5-10-fold lower in the CSF than in sera of corresponding patients, the concentration of TAL-H antibodies based on the total Ig content was enriched 50-100-fold in the CSF. An overall higher prevalence of TAL-H antibodies in the CSF compared with the sera also suggests that these antibodies may be locally produced at least in some of the patients. By contrast, under identical conditions antibodies to MBP were undetectable in sera or CSF from any of the patients with MS. However, it is possible that antibodies solely recognizing conformation-dependent epitopes remained undetected in Western blot analyses. Moreover, proliferative responses to TAL were significantly increased in comparison to MBP in patients with MS. In the presence of IL-2, proliferative responses were further increased in MS patients by TAL, suggesting that TAL-reactive cells may be activated in vivo in patients with MS (36). These findings are suggestive of the notion that TAL is a more potent immunogen than MBP in MS.

Antibodies to TAL were more prevalent in patients with $\mathrm{SI} \geq$ $2(11 / 14)$ in comparison with patients with $\mathrm{SI} \leq 2(3 / 11 ; P<$ $0.05)$. Correlation of cell- and antibody-mediated immune responses, which was observed in serial studies of the patients, may also indicate sensitization of the immune system to the normally sequestered TAL antigen in a subset of patients with MS. Individual variations in the extent of SIs and titers of TAL-specific antibodies are likely to reflect differences in $(a)$ prior exposures to environmental factors and $(b)$ genetic determinants influencing antigen recognition and persistence of autoimmune responses in MS $(1,12)$. An association was also noted between SIs in response to TAL and the more moderate proliferative responses to MBP. This correlation may reflect concurrent sensitization with TAL and MBP, perhaps secondary to destruction of oligodendrocytes in MS. Further, in accordance with a concurrent loss of MBP and TAL, immunohistochemical studies of four postmortem MS brain sections demonstrated loss of staining with MBP and TAL antibodies in demyelinating lesions. These findings were consistent with previous studies revealing that similar to MBP, TAL is expressed at selectively high levels in oligodendrocytes in the hu- man brain (16). Duration of disease or age of onset did not appear to be factors influencing $\mathrm{T}$ cell responses or antibody production against TAL. In fact, high titer antibodies and T cell responses were also detectable in a patient with acute MS (ROB, Table II). Neither humoral nor cell-mediated immunoreactivities to TAL varied with disease type or disease activity, suggesting that autoreactivity to TAL may indeed reflect a state of sensitization against the antigen and could thus serve as a stable marker of the disease. Early appearance and persistence of TAL reactivity may be compatible with an initiating role for immune recognition of TAL in the triggering phase and/or relapses of MS. These possibilities are particularly intriguing based on amino acid sequence homologies and immunological cross-reactivities between TAL and core proteins of human retroviruses (16).

Catalytic activity of rTAL-H was also inhibited in the presence of purified Igs from MS patients ALV and LAK. These data demonstrated that high affinity autoantibodies from patients with MS recognized not only the immunoblotted fulllength TAL-H protein and its $\mathrm{NH}_{2}$-terminal fragment (16) but functionally relevant $\mathrm{COOH}$-terminal epitopes as well (38). The presence of autoantibodies to multiple TAL-H epitopes and the enzyme inhibitory capacity of a subset of autoantibodies suggests that the intact TAL-H protein has become the source of antigenic drive in these patients. This points to a loss of tolerance as the fundamental lesion in TAL-H-specific autoimmunity in MS. Thus, molecular mimicry between a foreign and self-protein which is usually considered as an initiating factor in autoimmunity (16) may lead to an expanded autoimmune response against the entire molecule (39).

Use of the TCR V gene repertoire and its role in mediating demyelination in MS is a controversial issue. Involvement of the TCR in disease pathogenesis was suggested by overrepresentation of a polymorphic HindIII site in the TCR $\beta$ chain locus (40) and skewing of TCR $\alpha$-chain polymorphisms in MS patients (41). A skewed TCR V $\alpha$ usage in genetically identical twins with MS pointed towards the importance of exogenous factors in shaping both the TCR repertoire and the disease process $(42,43)$. In accordance with these findings, in this study a significant skewing of the TCR V $\beta$ repertoire was also observed in unstimulated PBL of all six MS patients as compared to controls. While there was no significant overlap among reports on TCR usage by MBP-specific T cells from peripheral blood of MS patients as recently reviewed (1), two independent studies showed a preferential usage of TCR V 35.2 and V $\beta 6.1$ by MBP-reactive peripheral $\mathrm{T}$ cells (44) and relative overexpression of TCR V $\beta 5.2$ and V $\beta 6$ in MS plaques (45, 46). However, it has become clear that as a general rule TCR $\mathrm{V}$ gene usage in MS may not be so limited (47-50). In the present study, upon stimulation by TAL-H, T cells bearing 15 distinct TCR V $\beta$ gene segments were found to be expanded to different extent, suggesting an overall diversity of TCR V $\beta$ usage in response to TAL-H in MS patients. Use of individual TCR V $\beta$ segments in response to MBP was increased less than twofold in patients with MS. Whereas skewing of any V $\beta$ in response to TAL-H was also less than twofold in healthy controls, usage of $\mathrm{V} \beta 1,2,3,4,5,6,8,9,10,11,14,15,18,20$, and 22 were differentially increased ranging from 2.5-65.9-fold with TAL-H-reactive $\mathrm{V} \beta$ families making up as much as 21 to $59 \%$ of the TCR V $\beta$ repertoire in patients with MS. Profound skewing of a diverse repertoire of TCR V $\beta$ genes in response to stimulation with TAL may represent a primarily antigen 
driven polyclonal immune response and a state of sensitization to the immunogen. In summary, the data suggest that autoreactivity to TAL may be of pathogenetic and diagnostic significance in a subset of patients with MS.

\section{Acknowledgments}

We thank Dr. John Wolf for referring his patients to us and David Halladay for technical assistance.

Matching CSF and serum samples from patients with MS were kindly provided by W.W. Tourtelotte from the National Neurological Research Specimen Bank, Veterans Administration Medical Center, Los Angeles, CA, which is sponsored by the Department of Veteran Affairs, National Institute of Neurological Disorders and Stroke/National Institute of Mental Health, and National Multiple Sclerosis Society. MS brain tissue specimen were obtained from the Colorado Multiple Sclerosis Center which is supported by the National Multiple Sclerosis Society grant RG 2108-C-6. This work was supported in part by grant R01 DK 49221 from the National Institutes of Health, the Central New York Community Foundation, and grants RG 2466A1/3 and RG 2108-C-6 from the National Multiple Sclerosis Society.

\section{References}

1. Martin, R., H.F. McFarland, and D.E. McFarlin. 1992. Immunological aspects of demyelinating diseases. Annu. Rev. Immunol. 10:153-187. (Review)

2. Traugott, I., E.L. Reinherz, and C.S. Raine. 1983. Multiple sclerosis: distribution of T-cell subsets within active chronic lesions. Science (Wash. DC). 219:308-310.

3. Booss, J., M.M. Esiri, and W.W. Tourtellotte. 1983. Immunohistochemical analysis of T-lymphocyte subsets in the central nervous system in chronic progressive multiple sclerosis. J. Neurol. Sci. 62:19-32.

4. Hauser, S.L., A.K. Bhan, and F. Gilles. 1986. Immunohistochemical analysis of the cellular infiltrate in multiple sclerosis lesions. Ann. Neurol. 19:578587.

5. Traugott, U., L.C. Scheinberg, and C.S. Raine. 1985. On the presence of Ia-positive endothelial cells and astrocytes in multiple sclerosis lesions and its relevance to antigen presentation. J. Neuroimmunol. 8:1-14.

6. Fujinami, R.S., and M.B. Oldstone. 1985. Amino acid homology between the encephalitogenic site of myelin basic protein and virus: mechanism for autoimmunity. Science (Wash. DC). 230:1043-1045.

7. Shaw, S.Y., R.A. Laursen, and M.B. Lees. 1986. Analogous amino acid sequences in myelin proteolipid and viral proteins. FEBS (Fed. Eur. Biol. Soc.) Lett. 207:266-270.

8. Query, C.C., and J.D. Keene. 1987. A human autoimmune protein associated with U1 RNA contains a region of homology that is cross-reactive with retroviral p30 gag antigen. Cell. 51:211-220.

9. Antel, J.P., and N.R. Cashman. 1991. Human retrovirus and multiple sclerosis. Mayo Clin. Proc. 66:752-755.

10. Perl, A., and K. Banki. 1993. Human endogenous retroviral elements and autoimmunity: data and concepts. Trends Microbiol. 1:153-156.

11. Murphy, P.M. 1993. Molecular mimicry and the generation of host defense protein diversity. Cell. 72:823-826.

12. Steinman, L. 1996. Multiple sclerosis: a coordinated immunological attack against myelin in the central nervous system. Cell. 85:299-302.

13. McCarron, R.M., R.J. Fallis, and D.E. McFarlin. 1990. Alterations in T cell antigen specificity and class II restriction during the course of chronic relapsing experimental allergic encephalomyelitis. J. Neuroimmunol. 29:73-79.

14. Whitham, R.H., R.E. Jones, G.A. Hashim, C.M. Hoy, R.Y. Wang, and A.A. Vandenbark. 1991. Location of a new encephalitogenic epitope (residues 43 to 64 ) in proteolipid protein that induces relapsing experimental autoimmune encephalomyelitis in $\mathrm{PL} / \mathrm{J}$ and $(\mathrm{SJL} \times \mathrm{PL}) \mathrm{F} 1$ mice. J. Immunol. 147: 3803-3808.

15. Lees, M.B., and S.W. Brostoff. 1984. Proteins of myelin. In Myelin. P. Morrell, editor. Plenum Publishing Corp., New York. 197-224.

16. Banki, K., E. Colombo, F. Sia, D. Halladay, D. Mattson, A. Tatum, P. Massa, P.E. Phillips, and A. Perl. 1994. Oligodendrocyte-specific expression and autoantigenicity of transaldolase in multiple sclerosis. J. Exp. Med. 180: 1649-1663.

17. Banki, K., D. Halladay, and A. Perl. 1994. Cloning and expression of the human gene for transaldolase: a novel highly repetitive element constitutes an integral part of the coding sequence. J. Biol. Chem. 269:2847-2851.

18. Mayes, P. 1993. The pentose phosphate pathway and other pathways of hexose metabolism. In Harper's Biochemistry. R. Murray, D. Granner, P.
Mayes, and V. Rodwell, editors. Appleton \& Lange, Norwalk, CT. 201-211.

19. Jacobson, S. 1963. Sequence of myelination in the brain of the albino rat. J. Comp. Neurol. 121:5-29.

20. McDougal, D.B., Jr., D.W. Schulz, J.V. Passonneau, J.R. Clark, M.A. Reynolds, and O.H. Lowry. 1961. Quantitative studies of white matter. I. Enzymes involved in glucose 6-phosphate metabolism. J. Gen. Physiol. 44:487498.

21. Baquer, N.Z., J.S. Hothersall, P. McLean, and A.L. Greenbaum. 1977. Aspects of carbohydrate metabolism in developing brain. Developmental Medicine \& Child Neurology. 19:81-104.

22. Balazs, R. 1970. Carbohydrate metabolism. In Handbook of Neurochemistry. A. Lajtha, editor. Plenum Press, New York. 1-36.

23. Hotta, S.S. 1962. Glucose metabolism in brain tissue: the hexose-monophosphate shunt and its role in glutathione reduction. J. Neurochem. 9:43-51.

24. Tan, E.M., A.S. Cohen, J.F. Fries, A.T. Masi, D.J. McShane, N.F. Rothfield, J.G. Schaller, N. Talal, and R.J. Winchester. 1982. The 1982 revised criteria for the classification of systemic lupus erythematosus. Arthr. Rheum. 25: 1271-1277.

25. Poser, C.M., D.W. Paty, L. Scheinberg, W.I. McDonald, F.A. Davis, G.C. Ebers, K.P. Johnson, W.A. Sibley, W.H. Silberberg, and W.W. Tourtellotte. 1983. New diagnostic criteria for multiple sclerosis: guidelines for research protocols. Ann. Neurol. 13:227-231.

26. Smith, D.B., and K.S. Johnson. 1988. Single-step purification of polypeptides expressed in Escherichia coli as fusions with glutathione S-transferase. Gene (Amst.). 67:31-40.

27. Pontremoli, S., D.B. Prandini, A. Bonsignore, and B.L. Horecker. 1961. The preparation of crystalline transaldolase from Candida utilis. Proc. Natl. Acad. Sci. USA. 47:1942-1955.

28. Deibler, G.E. , R.E. Martenson, and M.W. Kies. 1972. Large scale preparation of myelin basic protein of several mammalian species. Prep. Biochem. 2 $139-165$.

29. Towbin, H.H., T. Staehelin, and J. Gordon. 1979. Electrophoretic transfer of proteins from polyacrylamide gels to nitrocellulose sheets: procedure and some applications. Proc. Natl. Acad. Sci. USA. 76:4350-4354.

30. Perl, A., R. Gonzalez-Cabello, I. Lang, and P. Gergely. 1984. Effector activity of $\mathrm{OKT}_{4}^{+}$and $\mathrm{OKT}^{+}{ }^{+}$-cell subsets in lectin-dependent cell-mediated cytotoxicity against adherent HEp-2 cells. Cell. Immunol. 84:185-193.

31. Dawson-Saunders, B., and R.G. Trapp. 1994. Basic and Clinical Biostatistics. Appleton \& Lange, Norwalk, CT. 344 pp.

32. Chomczynski, P., and N. Sacchi. 1987. Single step method of RNA isolation by acid guadinium-isothiocyanate-phenol-chloroform extraction. Anal. Biochem. 162:156-159.

33. Genevee, C., A. Diu, J. Nierat, A. Caignard, P. Dietrich, L. Ferradini, S Roman-Roman, F. Triebel, and T. Hercend. 1992. An experimentally validated panel of subfamily-specific oligonucleotide primers (V $\alpha 1-w 29 / V \beta 1-w 24)$ for the study of human $\mathrm{T}$ cell receptor variable $\mathrm{V}$ gene segment usage by polymerase chain reaction. Eur. J. Immunol. 22:1261-1269.

34. Gulwani-Akolkar, B., P.N. Akolkar, A. Minassian, R. Pergolizzi, M. McKinley, G. Mullin, S. Fisher, and J. Silver. 1996. Selective expansion of specific T cell receptors in the inflamed colon of Crohn's disease. J. Clin. Invest. 98: 1344-1354.

35. Vandenbark, A.A., G. Hashim, and H. Offner. 1993. TCR peptide therapy in autoimmune diseases. Int. Rev. Immunol. 9:251-276. (Review.)

36. Zhang, J., S. Markovic-Plese, B. Lacet, J. Raus, H.L. Weiner, and D.A Hafler. 1994. Increased frequency of interleukin 2-responsive T cells specific for myelin basic protein and proteolipid protein in peripheral blood and cerebrospinal fluid of patients with multiple sclerosis. J. Exp. Med. 179:973-984.

37. Perl, A., R. Gonzalez-Cabello, K. Onody, I. Bodo, and P. Gergely. 1986. Independence of depressed lectin-dependent cell-mediated cytotoxicity from interleukin 2 production in patients with systemic lupus erythematosus. Clin. Exp. Immunol. 65:286-292.

38. Banki, K., and A. Perl. 1996. Inhibition of the catalytic activity of human transaldolase by antibodies and site-directed mutagenesis. FEBS (Fed. Eur. Biol. Soc.) Lett. 378:161-165.

39. James, J.A., T. Gross, R.H. Scofield, and J.B. Harley. 1995. Immunoglobulin epitope spreading and autoimmune disease after peptide immunization: Sm B/B'-derived PPPGMRPP and PPPGIRGP induce spliceosome autoimmunity. J. Exp. Med. 181:453-461.

40. Seboun, E., M.A. Robinson, T.H. Doolittle, T.A. Ciulla, T.J. Kindt, and S.L. Hauser. 1989. A susceptibility locus for multiple sclerosis is linked to the T cell receptor $\beta$ chain complex. Cell. 57:1095-1100.

41. Oksenberg, J.R., M. Sherritt, A.B. Begovich, H.A. Erlich, C.C. Bernard, L.L. Cavalli-Sforza, and L. Steinman. 1989. T-cell receptor V $\alpha$ and $\mathrm{C} \alpha$ alleles associated with multiple sclerosis and myasthenia gravis. Proc. Natl. Acad. Sci. USA. 86:988-992.

42. Utz, U., W.E. Biddison, H.F. McFarland, D.E. McFarlin, M. Flerlage, and R. Martin. 1993. Skewed T-cell receptor repertoire in genetically identical twins correlates with multiple sclerosis. Nature (Lond.). 364:243-247.

43. Utz, U., R. Martin, J.A. Brooks, W.E. Biddison, and H.F. McFarland. 1995. T-cell receptor use in multiple sclerosis. Ann. NY Acad. Sci. 756:259-264. 44. Kotzin, B.L., S. Karutiri, Y.K. Chou, J. Lafferty, J.M. Forrester, M. Better, G.E. Nedwin, H. Offner, and A.A. Vandenbark. 1991. Preferential T cell 
receptor $\beta$-chain variable gene use in myelin basic protein reactive $\mathrm{T}$ cell clones from patients with multiple sclerosis. Proc. Natl. Acad. Sci. USA. 88:9161-9165.

45. Oksenberg, J.R., M.A. Panzara, A.B. Begovich, D. Mitchell, H.A. Erlich, R.S. Murray, R. Shimonkevitz, M. Sherritt, J. Rothbard, C.C.A. Bernard, and L. Steinman. 1993. Selection for T-cell receptor V $\beta-D \beta-J \beta$ gene rearrangements with specificity for a myelin basic protein peptide in brain lesions of multiple sclerosis. Nature (Lond.). 362:68-70.

46. Shimonkevitz, R., R. Murray, and B. Kotzin. 1995. Characterization of $\mathrm{T}$-cell receptor $\mathrm{V} \beta$ usage in the brain of a subject with multiple sclerosis. Ann. NY Acad. Sci. 756:305-306.

47. Richert, J.R., E.D. Robinson, A.H. Johnson, C.A. Bergman, L.J. Dragovic, and C.K. Hurley. 1991. Heterogeneity of the T-cell receptor beta gene rearrangements generated in myelin basic protein-specific T-cell clones isolated from a patient with multiple sclerosis. Ann. Neurol. 29:299-306.

48. Wucherpfennig, K.K., J. Newcombe, H. Li, C. Keddy, M.L. Cuzner, and D.A. Hafler. 1992. T cell receptor $\mathrm{V} \alpha$-V $\beta$-repertoire and cytokine gene expression in active multiple sclerosis lesions. J. Exp. Med. 175:993-1002.

49. Martin, R., U. Utz, J.E. Coligan, J.E. Richert, M. Flerlage, E. Robinson, R. Stone, W.E. Biddison, D.E. McFarlin, and H.F. McFarland. 1992. Diversity in fine specificity and $\mathrm{T}$ cell receptor usage of the human $\mathrm{CD}^{+}$cytotoxic $\mathrm{T}$ cell response specific for the immunodominant myelin basic protein peptide 87-106. J. Immunol. 148:1359-1366.

50. Linington, C., and B. Waksman. 1995. The T-cell receptor in multiple sclerosis. Ann. NY Acad. Sci. 756:294-304. 